\title{
A SZÜLÖI EGÉSZSÉGTUDATOSSÁG ÉS AZ ÉTKEZÉSI PREFERENCIÁIK VIZSGÁLATA A GYERMEKKORI ELHÍZÁS TÜKRÉBEN
}

\author{
भ6 \\ PARENTAL HEALTH CONCIOUSNESS AND EXAMINATION OF EATING PREFERENCES \\ IN REFLECTION OF CHILDHOOD OBESITY
}

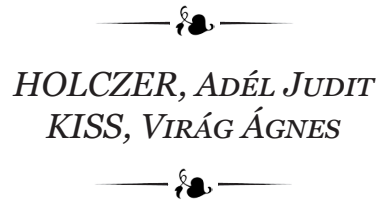

Debreceni Egyetem, Gazdaságtudományi Kar, Marketing és Kereskedelem Intézet (University of Debrecen, Faculty of Economics and Business, Institute of Marketing and Commerce) H-4032 Debrecen, Böszörményi út 138 .

e-mail: holczeradel@outlook.hu

\begin{abstract}
\& One of the 21st century's well-known megatrend is the healthy lifestyle and eating which is the basis of this research. We have already known some aspects of this topic, but the parental health consciousness and the examination of eating preferences is not as well known as it has to be, so this makes this study relevant. The goal of this exploratory research was to get to know more about the parental health consciousness, their eating preferences and attitudes, so Hungarian parents were asked who have children under 14 years old to tell more about their habits and lifestyle. In the primer research an online questionnaire was used which reaches 206 people so we could make some consequences about the lifestyle and the preferences of the families in Hungary. The main parts of this research were: the importance of health and the healthy lifestyle, the form of the parental research about the topic, which sources they find the most relevant and authentic, the parental eating habits, family health, the responsibility of the parents. During the statistical analysis some segments of people could be separated whose different attitudes and preferences were shown very clearly. It reveals of the results for example that the groups have different eating habits and researching systems.
\end{abstract}

KuLCSSZAVAK: egészség, egészséges életmód, szülői étkezési preferenciák, egészségtudatosság

JEL-KóDOK (JEL CODES): I12, M31

DOI: https://doi.org/10.20494/TM/6/2/3

\section{BEVEZETÉS - INTRODUCTION}

A kutatásunk alapjának a szülői nevelési attitűdök, valamint étkezési szokásaik, preferenciák vizsgálatát választottuk, kiegészítve a gyermekkori obezitás prevenciójával, amely napjainkban nagyon aktuális témának számít. A jelenkor gyermekei már beleszületnek egy rohanó világba, melynek fundamentumát az okostelefonok, tabletek, laptopok jelentik. Egy idő után arra lehetünk figyelmesek, hogy egyre inkább kimarad az a minőségi idő, amely jelen-
KEYWORDS: health, healthy lifestyle, parental eating preferences, health consciousness

tős részét a közös étkezések, szabadidős tevékenységek, családi programok és beszélgetések alkotják.

Ha azt szeretnénk, hogy egy helyesen gondolkodó és cselekvő, egészségtudatos társadalomban éljünk mi is és családunk tagjai is, a változást legszükebb mikrokörnyezetünkben érdemes elkezdeni. Minél hamarabb találkozik egy gyermek a helyes étkezési és életmódbeli szokásokkal, annál hamarabb válik számára természetessé, mindennapossá.

Ha a táplálkozáshoz kapcsolódó betegsé- 
geket elhelyezzük egy skálán, egyik oldalán a túlsúly és elhízás, másik végpontjában pedig az alultápláltság foglal helyet, amelyet bármely irányból is közelítünk meg, komoly problémának minősül, főleg a kisgyermekek körében. A téma relevanciáját alátámasztja, hogy bizonyítottan sokkal több napjainkban az elhízott, túlsúlyos, étkezési zavarral küzdő gyermek az előző generációkhoz képest. Bár a témához kapcsolódóan sok kutatást végeztek az elmúlt időben, mégis nagyon kevesen vizsgálták a betegségek kialakulásának kiindulópontját, a szülői preferenciákat, valamint attitűdöket. Feltétlenül szükséges lenne a szülők vásárlási szokásainak vizsgálata, hiszen minden bizonynyal ez a probléma egyik kiindulópontja. Fontos megismerni mit vásárolnak, milyen példát mutatnak, milyen felfogások, hiedelmek, egészséggel kapcsolatos elköteleződések figyelhetők meg náluk. A gyerekek tájékoztatása ezzel kapcsolatban épp olyan fontos lenne, mint a szorzótábla megismerése első osztályban. A probléma felismerése, megoldása elméleti síkon kevés. Csupán cselekedeteinkkel és akaratunkkal tudjuk megváltoztatni a berögződött rossz szokásokat, amelyek jótékony következményei hosszú távon lesznek érzékelhetők.

Kutatásunk célja, hogy rávilágítsunk arra, milyen fontos a gyerekek egészségtudatos életmódra való nevelése és megfelelő tájékoztatása a témával kapcsolatban, már egészen kiskortól kezdődően. Ezen belül kiemelten fontos a táplálkozás szerepe már kora gyerekkorban. Sokkal könnyebb lenne a gyerekeket már kiskoruktól kezdődően a helyes táplálkozásra, mértékletességre sarkallni, mint a már makacs, túlsúlyos tinédzsereket fogyókúrára fogni. Sajnos napjaink tapasztalata inkább az utóbbi, amelyben felmerül a szülői felelősség kérdése.

Céljaink között szerepel még felmérni a szülők vásárlási szokásait, preferenciáit és ezáltal betekintést nyerni egy átlagos magyar család hütőszekrényébe. Továbbá feltérképezni a véleményeket a gyerekek helytelen táplálkozási szokásait tekintve, mind a szülők és mind a szakemberek részéról, ennek fizikai, lelki és mentális hátterét egyaránt vizsgálva.

\section{SZAKIRODALMI ÁTTEKTINTÉS -}

\section{LITERATURE REVIEW}

Az egészséget különböző dimenziókra oszthatjuk, mely dimenziók jól elkülöníthetók egymástól, még sincs teljes jóllét az egyik, vagy másik hiányában.

Ugyanez a szegmentálhatóság figyelhető meg a szülői nevelési attitűdökre is, melyet a probléma összetettségét tekintve - érdemes részletesebben is megvizsgálni.

\subsection{Az egészség dimenziói - Health Dimensions}

Egyes szakirodalmak szerint az egészséget öt külön egységre oszthatjuk, ám együttesen tekinthetjük őket egy egésznek (HIDVÉGI et al., 2015):

- Biológiai egészség, amely magába foglalja szervezetünk hibátlan múködését, melyet szerveink összehangolt munkája tesz lehetővé.

- Lelki egészség, amely akár egy mérleg, ha kibillen egyensúlyából, hatást gyakorol egész testi jóllétünkre.

- Mentális egészség, amely lehetővé teszi tiszta, következetes gondolkodásunkat és segíti gondolataink helyes megfogalmazását.

- Emocionális egészség, amelynek segítségével képesek vagyunk nem csak gondolati síkon felismerni érzéseinket, hanem verbális, illetve nonverbális úton ezeket környezetünk tudtára adni.

- Szociális egészségünk pedig segíti a társadalomba való beilleszkedésünket, illetve társas kapcsolataink kialakítását.

Mások hat dimenziót állapítottak meg: az intellektuális, érzelmi, társadalmi, környezeti, szellemi, valamint a fizikai jóllétet, amelyek kölcsönösen hatnak egymásra (FAHEY et al., 2010).

Mindezek azt mutatják, hogy egy rendkívül komplex fogalomról beszélünk, amelyet különböző elemek összességének megléte jellemez és befolyásol. Habár fontossága elvitathatatlan, sokszor csak hiányakor észleljük. 


\subsection{A család szerepe a táplálkozásban} és a szülői attitüdök vizsgálata - The Role of the Family in Nutrition and the Study of Parenting Attitudes

A gyermek szocializációjának egyik legfontosabb színtere a család, amely egy olyan komplex rendszer, melyben a tagok kölcsönösen hatást gyakorolnak egymásra (SALLAY és MÜNNICH, 1999), illetve jelentős feladatot lát el az egyének személyiségfejlődésében (BUSI, 2004).

Az egészséges életmódra való nevelés egy olyan dolog, amit nem lehet elég korán elkezdeni, viszont sosem késő belevágni. Az egyének gondolkodásmódja, magatartása, attitűdje, értékrendje és normarendszere az, amelyet már gyermekkorban elsajátít és késóbb továbbadja a következő generációknak (PIKÓ, 2002). A gyermekkorban kialakult és rögzült táplálkozási és életmódbeli szokások csak nagyon minimális mértékben és nagy nehézségek árán változtathatók meg a későbbiekben (ÁBRAHÁM és CSATORDAI, 2006).

SZỨCS és SZÉLL (2013) szerint a szülők, közülük is leginkább az édesanyák az iránymutatók a gyermekeik életében, így a szülői szerepvállalás felelősségének is talán ez a legfőbb oka. Életmódjuk, szokásaik, viselkedési formáik követendő példaként állnak gyermekeik előtt. Bár erre talán nem is gondolnánk, de rendkívül fontos tényezőnek minősül a születési sorrend is (SUTTON-SMITH és ROSENBERG, 1966).

HOLDEN és EDWARDS (1989) a szülő és gyermek kapcsolat két dimenzióját különböztette meg. Az egyik a szülő és gyermek közti emocionális kapcsolatra vonatkozik, a másik dimenzió pedig a kontroll fontosságát emeli ki a gyermeknevelésben.

A szülői bánásmód, nevelési szokások vizsgálatában uralkodó módszer a szülői-nevelői attitűdökre vonatkozó kérdőívek használata, például a PARI (SCHAEFER és BELL, 1958), CRPR (BLOCK, 1965) és MAS (COHLER et al., 1970) tesztek. Ezek szinte minden esetben általános nevelési elvekre és konkrét viselkedésformákra, illetve viselkedési szándékra kérdeznek rá (TÓTH - GERVAI, 1999).

A BAUMRIND (1971) modell alapján három különböző szülői nevelési attitúdöt különböztethetünk meg. Az első az autoritativ, amelyben a szülő nem szab túl nagy korlátokat gyermekének, de jól meghatározott elvárásokat támaszt gyermeke felé azokon a területeken, amelyben ő maga is jártas. Segítik a gyermekük egészséges énképének kialakulását és megfelelő önértékelését. A második az autoritariánus, amelyben erőteljesebben megmutatkozik az alá-, fölérendelt viszony szülő és gyermeke között. A szülő ésszerútlen, túlzottan magas elvárásokat támaszt gyermeke felé, sokszor bünteti, ugyanakkor szükségleteit nem veszi figyelembe. A harmadik pedig az engedékeny szülői attitüd, melyben a kapcsolat érzelemteli, de a nevelési módszerekben nincs következetesség (SALLAY és MÜNNICH, 1999). Ezt a három nevelési attitúdöt Baumrind 1971-ben kiegészítette még az elhanyagoló, illetve involváltságtól mentes nevelési formával (SALLAY és MÜNNICH, 1999).

LANTOS és INÁNTSY-PAP (2012) a család hatása az étkezési szokásokra témában írt elemzést, melynek eredményeképp három szintet különböztethetünk meg. Az első szint a táplálkozáshoz közvetlenül kapcsolódó viselkedésmódok, a második szint a szülők viselkedése általánosan az étkezés kapcsán, a harmadik szint a globális szülői viselkedés.

Marketing szempontból viszont érdemes a gyerekeket is figyelembe vennünk, hiszen manapság már speciális szerepet töltenek be a vásárlási és fogyasztási folyamatokban (HORVÁTH, 1996), ugyanis egyre inkább gazdaságformáló erőként jelennek meg társadalmunkban (SULYOKNÉ GUBA, 2000). Egy felmérések szerint már az óvodások is, mint önálló vásárlóerő és saját tudattal rendelkező fogyasztó jellemezhetőek (LIPI, 2000).

Ezek alapján jól látszik, hogyha egy egészségtudatosabb társadalomban szeretnénk élni, már az egészen kicsi gyermekek nevelésénél érdemes elkezdenünk a megfelelő szokások kialakítását. Ha pozitív példát mutatunk gyermekeinknek, remélhetőleg ők is ezt az értékrendet fogják továbbörökíteni a következő generációra. 
3. ANYAg ÉS MÓDSZER - MATERIAL AND METHOD

Feltáró kutatásunk (LEHOTA, 2001) célját képezte a különböző szülői attitűdök, illetve preferenciák vizsgálata, melynek keretein belül olyan Magyarországon élő édesanyákat és édesapákat kérdeztünk meg, akiknek 0-14 év közötti gyermekei vannak. A kutatást országos szinten végeztük, csupán egy régióból nem érkezett kitöltés, illetve egy régióban egy kitöltésünk lett, mégis fontosnak tartottuk, hogy eszerint is megvizsgáljuk a mintasokaságot (1a és $1 b$. táblázat).

Online, anonim kérdőíves megkérdezést alkalmaztunk, amelyet 206-an töltöttek ki, így bár nem minősül reprezentatívnak a kutatás, mégis úgy gondoljuk a fóbb gondolatok, irányelvek már tetten érhetők a szülők étkezési és nevelési szokásaikat tekintve. A kérdőív túl- nyomó többségben az anyukákat érte el.

Összesen 29 kérdést fogalmaztunk meg, melyből nyolc a háttérváltozók feltárására irányult. A kérdések között zárt, illetve skála típusúak szerepeltek, melyek megfogalmazásakor direkt és indirekt módszert is alkalmaztunk. A zárt kérdések között egy, illetve többváltozós, a skála típusúaknál pedig nominális, ordinális típusú, valamint Likert skálák is szerepeltek.

Kutatásunk főbb témakörei: az egészség és az egészséges életmód fontossága, a szülői tájékozódás formái és módja a témát illetően, a használt források hitelessége, a családok étkezési szokásai, a szülők és gyermekeik egészségi állapota, a szülői felelősségvállalás, illetve az elhízással kapcsolatos kérdéskörök.

Az eredmények feldolgozásához az SPSS program statisztikai elemzéseit használtunk, ezen belül is jellemzően leíró, megoszlási mutatók, kereszttábla elemzés készítettünk.

1a. TÁBLÁZAT

TABLE $1 a$

A válaszadók megoszlása a háttérváltozók szerint $(\mathrm{N}=\mathbf{2 0 6})$ (Demographical Background of the Sample)

\begin{tabular}{|c|c|c|}
\hline & Fö (Capita) & $\%$ \\
\hline \multicolumn{3}{|c|}{ A válaszadók megoszlása nemek szerint (Gender) } \\
\hline Nő (Woman) & 195 & 94,7 \\
\hline Férfi (Man) & 11 & 5,3 \\
\hline \multicolumn{3}{|c|}{ A válaszadók megoszlása korcsoport szerint (Age groups) } \\
\hline $18-25$ & 11 & 5,3 \\
\hline $26-30$ & 24 & 11,7 \\
\hline 31-35 & 42 & 20,4 \\
\hline $36-40$ & 52 & 25,2 \\
\hline $41-45$ & 60 & 29,1 \\
\hline $46-50$ & 9 & 4,4 \\
\hline 50 felett (Over 50$)$ & 8 & 3,9 \\
\hline \multicolumn{3}{|c|}{ A válaszadók megoszlása lakóhely szerint (Settlement type) } \\
\hline Főváros (Capital city) & 10 & 4,9 \\
\hline Megyeszékhely (County seat) & 52 & 25,2 \\
\hline Város (City) & 84 & 40,8 \\
\hline Község (Village) & 60 & 29,1 \\
\hline
\end{tabular}

Forrás (Source): Saját szerkesztés, kérdőíves felmérés alapján, 2018 (Own compilation based on guestionnaire survey, 2018) 


\section{A válaszadók megoszlása a háttérváltozók szerint $(\mathrm{N}=206)$ (Demographical Background of the Sample, $N=206$ )}

\begin{tabular}{|c|c|c|}
\hline & Fö (Capita) & $\%$ \\
\hline \multicolumn{3}{|c|}{ A válaszadók megoszlása iskolai végzettség szerint (Educational level) } \\
\hline Maximum 8 általános (Elementary school) & o & o \\
\hline Szakmunkásképző/ Szakiskola (Voluntary school) & 22 & 10,7 \\
\hline Gimnázium (High school) & 39 & 18,9 \\
\hline Felsőfokú végzettség (Higher education) & 145 & 70,4 \\
\hline \multicolumn{3}{|c|}{ A válaszadók megoszlása családi állapot szerint (Marital status) } \\
\hline Egyedülálló (Single) & 10 & 4,9 \\
\hline Élettársi kapcsolatban élő (Woman) & 37 & 18,0 \\
\hline Házas (Married) & 146 & 70,9 \\
\hline Elvált vagy külön él (Divorced) & 13 & 6,3 \\
\hline \multicolumn{3}{|c|}{ A válaszadók megoszlása régió szerint (Regions) } \\
\hline Nyugat-Dunántúl (Western Transdanubia) & 48 & 23,3 \\
\hline Közép-Dunántúl (Central Transdanubia) & 74 & 35,9 \\
\hline Dél-Dunántúl (Southern Transdanubia) & 1 & 0,5 \\
\hline Közép-Magyarország (Central Hungary) & 23 & 11,2 \\
\hline Észak-Magyarország (Northern Hungary) & 12 & 5,8 \\
\hline Észak-Alföld (Northern Great Plain) & 48 & 23,3 \\
\hline \multicolumn{3}{|c|}{ A válaszadók megoszlása a háztartás mérete szerint (Household size - capita) } \\
\hline 1 & 1 & 0,5 \\
\hline 2 & 10 & 4,9 \\
\hline 3 & 78 & 37,9 \\
\hline 4 & 73 & 35,4 \\
\hline 5 & 37 & 18,0 \\
\hline $5^{+}$ & 7 & 3,4 \\
\hline \multicolumn{3}{|c|}{ A válaszadók megoszlása havi jövedelem szerint (Income) } \\
\hline $\begin{array}{l}\text { Jövedelmemből mindenre futja, sôt félre is tudok tenni (Can } \\
\text { live on it very well and can also save) }\end{array}$ & 104 & 50,5 \\
\hline $\begin{array}{l}\text { Nincsenek anyagi gondjaim, de félre már nem tudok tenni } \\
\text { (Can live it well, but cannot save) }\end{array}$ & 84 & 40,8 \\
\hline $\begin{array}{l}\text { Jövedelmem éppen csak fedezi a költségeimet (Just enough to } \\
\text { make ends meet) }\end{array}$ & 16 & 7,8 \\
\hline $\begin{array}{l}\text { Jövedelmem még a költségeimet sem fedezi (Sometimes } \\
\text { cannot make ends meet) }\end{array}$ & 2 & 1,0 \\
\hline $\begin{array}{l}\text { Jövedelmemből mindenre futja, sőt félre is tudok tenni (Can } \\
\text { live on it very well and can also save) }\end{array}$ & 104 & 50,5 \\
\hline
\end{tabular}

Forrás (Source): Saját szerkesztés, kérdőíves felmérés alapján, 2018 (Own compilation based on guestionnaire survey, 2018) 


\section{EREDMÉNYEK - Results}

Úgy gondoljuk, hogy feltáró kutatásunk eredményei jó alapját képezhetik egy nagyobb mintaszámú, reprezentatív kutatásnak, amelyben árnyaltabban lehetne az alábbi kérdésköröket megvizsgálni.

\subsection{Az egészség dimenzióinak fontossá- ga és a saját egészségi állapot szub- jektív megítélése - The Importance of Health Dimensions and Subjective Judgment of One's Own Health}

Kutatásunk egyik legérdekesebb eredményének az egészségdimenziók fontosságának eltérő megítélését tartjuk. Bár a módusza mindegyiknek öt, a válaszadók mégis a lelki egészséget ítélték a legfontosabbnak, amely az elmúlt évtizedekhez képest nagy eltérést mutat. A biológiai, vagyis fizikai egészséget megelőzi továbbá a mentális egészség fontossága, amely két eredmény jól mutatja, hogy az emberek többsége már nem kizárólag a fizikai jólléttel azonosítja az egészség fogalmát (1. ábra).

\subsection{A szülői tudatosság - Parental Consciousness}

A 2. táblázat állításait Likert skálán értékelték a kitöltók egyetértésük mértéke szerint, ahol az 5 a teljesen mértékben egyetért, az 1 pedig a nem ért egyet kategóriák voltak.

A 2. táblázat alapján jól megmutatkozik a szülői felelősségvállalás és példamutatás fontosságának mértéke, melyet a legmagasabbra értékeltek. A tudatosság fokát mutatja továbbá, hogy a szülők többségét érdekli, valamint fel is használja az egészséges életmóddal kapcsolatban olvasottakat és hallottakat. További reményre ad okot, hogy sokan már a terhességük előtt is egészséges életmódot folytattak, akik pedig nem, azok többsége életmódot váltott várandóssága alatt, valamint a legtöbben különös figyelmet szenteltek a megfelelő vitaminok fogyasztására ebben az időszakban. Elenyésző arányban fordultak csak elő olyanok, akik bolti babaételt vásároltak, tehát az édesanyák közül szinte mindenki jellemzően saját maga készítette/készíti a babapépeket a hozzátáplálás során. Kiemelten fontosnak tartják továbbá a szűrővizsgálatokat, valamint felismerik a gyermekkori elhízás prevenciójában rejlő hasznosságot, amely a problémamegoldás kiindulópontjának tekinthető. Ugyanakkor az is megfigyelhető, hogy a szülők nincsenek teljes mértékben megelégedve az iskolai tájékoztatás mértékével a témát illetően.

\section{1. ÁBRA}

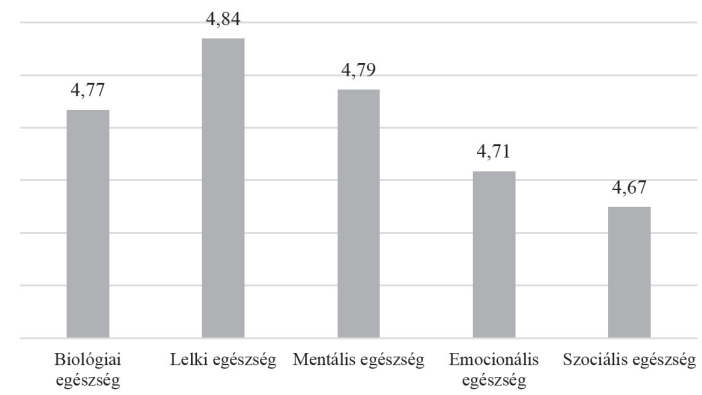

Az egészségdimenziók fontosságának megoszlása, átlagérték

FIG. 1 (Importance of Health Dimensions, mean)

Forrás (Source): Saját kutatás alapján, 2018 (Based on own research, 2018)

Megjegyzés (Notes): biológiai egészség (biological health), lelki egészség (psychical health), mentális egészség (mental health), emocionális egészség (emotional health), szociális egészség (social health) 
A válaszadók megoszlása az egészségtudatosságukkal kapesolatos állítások alapján ( $\mathrm{N}=206)$ (Health-Conscious Attitudes of the Respondents, $N=206$ )

\begin{tabular}{|c|c|c|c|}
\hline $\begin{array}{c}\text { Állítások } \\
\text { (Statements) }\end{array}$ & $\begin{array}{c}\text { Átlag } \\
\text { (Mean) }\end{array}$ & $\begin{array}{l}\text { Medián } \\
\text { (Median) }\end{array}$ & $\begin{array}{l}\text { Módusz } \\
\text { (Mode) }\end{array}$ \\
\hline $\begin{array}{l}\text { Fontos a példamutatás az egészséges életmódban is a gyermekek számá- } \\
\text { ra (Leading role models for children is very important) }\end{array}$ & 4,75 & 5,00 & 5,00 \\
\hline $\begin{array}{l}\text { Egy gyermek egészséges életmódjának kialakítása a szülő felelőssége } \\
\text { (It is the parent's responsibility to develop a healthy lifestyle for their } \\
\text { child) }\end{array}$ & 4,72 & 5,00 & 5,00 \\
\hline $\begin{array}{l}\text { A gyermekem nevelésénél szem előtt tartom az egészséges életmód kér- } \\
\text { déskörében hallott, olvasott ajánlásokat (I follow the recommendations } \\
\text { I have heard and read about healthy living) }\end{array}$ & 4,24 & 4,00 & 4,00 \\
\hline $\begin{array}{l}\text { Nagyon érdekelnek az egészséges életmód lehetőségei és kérdéskörei (I } \\
\text { am very interested in the opportunities and issues of a healthy lifestyle) }\end{array}$ & 3,96 & 4,00 & 4,00 \\
\hline $\begin{array}{l}\text { Már a gyermekvállalás előtt is egészséges életmódot folytattam (Even } \\
\text { before I had a baby, I had had a healthy lifestyle) }\end{array}$ & 3,65 & 4,00 & 4,00 \\
\hline $\begin{array}{l}\text { Várandóságom alatt életmódot váltottam, egészségesebben kezdtem el } \\
\text { táplálkozni, mint előtte (During my pregnancy I changed my lifestyle } \\
\text { and started eating healthier than before) }\end{array}$ & 3,51 & 4,00 & 4,00 \\
\hline $\begin{array}{l}\text { Gyermekemnek általában boltban vásároltam a babaételt (I usually } \\
\text { bought the baby food for my child) }\end{array}$ & 2,45 & 2,00 & 2,00 \\
\hline $\begin{array}{l}\text { Gyermekemnek a hozzátápláláskor inkább saját magam készítettem a } \\
\text { babaételt (I usually made or cooked the baby food for my child myself) }\end{array}$ & 3,91 & 4,00 & 5,00 \\
\hline $\begin{array}{l}\text { Terhességem alatt különösen figyeltem a megfelelő vitaminok fogyasztá- } \\
\text { sára (During my pregnancy I paid particular attention to get the right } \\
\text { vitamins) }\end{array}$ & 4,28 & 5,00 & 5,00 \\
\hline $\begin{array}{l}\text { Fontos a gyermekek egészségtudatosságra való nevelése (It is important } \\
\text { to educate children on health awareness) }\end{array}$ & 4,82 & 5,00 & 5,00 \\
\hline $\begin{array}{l}\text { A gyermekek az iskolában megfelelő tájékoztatást kapnak az egészséges } \\
\text { életmód fontosságáról (Children at school are properly informed about } \\
\text { the importance of a healthy lifestyle) }\end{array}$ & 3,07 & 3,00 & 3,00 \\
\hline $\begin{array}{l}\text { Fontosak a szürővizsgálatok a gyermekek számára is (Health tests are } \\
\text { also important for children) }\end{array}$ & 4,65 & 5,00 & 5,00 \\
\hline $\begin{array}{l}\text { Kiemelten fontos a gyermekkori elhízás prevenciója (The prevention of } \\
\text { childhood obesity is of paramount importance) }\end{array}$ & 4,63 & 5,00 & 5,00 \\
\hline $\begin{array}{l}\text { A gyermekek és szüleik alulértékelik az elhízás következményeit } \\
\text { (Children and their parents underestimate the consequences of obesity) }\end{array}$ & 4,30 & 5,00 & 5,00 \\
\hline $\begin{array}{l}\text { A túlsúlyos gyermekek általában nehezebben illeszkednek be egy közös- } \\
\text { ségbe (Obese children are generally more difficult to integrate into a } \\
\text { community) }\end{array}$ & 3,81 & 4,00 & 4,00 \\
\hline
\end{tabular}

Forrás (Source): Saját kutatás alapján, 2018 (Based on own research, 2018) 


\subsection{A szülők információszerzésének módja és preferenciáik - Parents' Information Sources and Preferences}

A 3. illetve az 4. táblázat keretein belül megvizsgáltuk a szülői preferenciákat, az információ forrását, illetve azok hitelességét tekintve.

A két táblázatot összehasonlítva jól látszik, hogy toronymagasan vezetnek az orvosok, ha a forrás helyét, illetve a szavahihetőségének mértékét vizsgáljuk. Ez azért fontos eredmény, mivel ók számítanak a legelhallgatottabb csoportnak az egészséges életmódot, valamint táplálkozást tekintve. A kutatás alapján viszont megállapíthatjuk, hogy e témához kapcsolódó termékek, illetve szolgáltatások népszerüsítésében az orvosok szakvéleménye a termék vagy szolgáltatás megbízhatóságát, hitelességét jelenti a nagyközönség számára. Ugyanebbe a kategóriába sorolhatók a szakkönyvek is, hiszen második helyen jelennek meg a felhasználást, illetve az információ minőségét tekintve. Érdekes megfigyelni, hogy a szintén szakembernek számító dietetikusok az információ forrását tekintve a középmezőnyben foglalnak helyet, míg a megbízhatóságukat nézve az elökelő harmadik helyet érték el. Ennek oka lehet, hogy a legtöbb dietetikus magánpraktizál, így a szolgáltatásuk költségét nem mindenki tudja magának megengedni. Még mindig az élboly- ba sorolandók a védőnők, illetve a saját szülők véleménye.

A középmezőnyben helyet foglaló, manapság nagyon divatosnak számító táplálkozási tanácsadók, megbízhatóságukat tekintve viszszacsúsztak a lista utolsó harmadába. Ennek oka a szolgáltatás magas ára lehet. Egy jól menő táplálkozási tanácsadó akár 20-30 ezer forintot is elkér egy étrend megírásáért, amely minden bizonnyal nem tekinthető reálisnak, mivel a legtöbb képesítést nyújtó tanfolyam mindössze pár alkalmat vesz igénybe. Természetesen általánosítani nem lehet, mivel sokan egészségügyi tanulmányaikat egészítik ki ezzel a végzettséggel.

Mindkét lista végén a közösségi fórumok, rendezvények, illetve a bloggerek, vloggerek foglalnak helyet. Az utóbbiak rangsorban elfoglalt helye, információforrásként való múködésüket tekintve, meglepőnek mondható, hiszen egyre népszerúbbek a már influencernek számító blogot, illetve Youtube csatornát vezető közösségi média szereplők. A megbízhatóságuk alacsony mértéke azonban nem okozott túl nagy meglepetést (4. táblázat). Ennek oka lehet, hogy a mostani fiatal felnőttek és a gyerekek körében örvendenek igazán nagy népszerüségnek és véleményvezérnek ezek az online médiaszereplők. 
A válaszadók megoszlása információszerzésük alapján, $\mathrm{N}=\mathbf{2 0 6}$ (Sources of Information About Healthy Lifestyle, $N=206$ )

\begin{tabular}{llc}
\hline \multicolumn{1}{c}{$\begin{array}{c}\text { Információforrás } \\
\text { (Information source) }\end{array}$} & $\begin{array}{c}\text { Fó } \\
\text { (Capita) }\end{array}$ & $\begin{array}{c}\text { Információ } \\
\text { felhasználásának } \\
\text { mértéke, \% (The extent } \\
\text { of information usage, } \\
\text { \%) }\end{array}$ \\
\hline Orvos (Practitioner) & 183 & 89,7 \\
\hline Szakkönyvek (Professional literature) & 174 & 85,3 \\
\hline Saját szüló véleménye (Own parent's opinion) & 165 & 80,9 \\
\hline Védónői vélemény (Nurse's opinion) & 149 & 73,0 \\
\hline Gyermekpedagógus véleménye (Teacher's opinion) & 108 & 52,9 \\
\hline Gyógyszerész véleménye (Pharmacist's opinion) & 102 & 50,0 \\
\hline Újságcikk (Article) & 102 & 50,0 \\
\hline Más anyukák véleménye (Other mother's opinion) & 100 & 49,0 \\
\hline Dietetikus véleménye (Dietetian's opinion) & 99 & 48,5 \\
\hline Táplálkozási tanácsadó véleménye (Dietetic consultant's opinion) & 83 & 40,7 \\
\hline Közösségi rendezvények (Events) & 77 & 37,7 \\
\hline Közösségi fórumok (Social Media) & 73 & 35,8 \\
\hline Természetgyógyász véleménye (Naturopath's opinion) & 62 & 30,4 \\
\hline Bloggerek,Vloggerek véleménye (Bloggers, Vloggers) & 35 & 17,2 \\
\hline
\end{tabular}

Forrás (Source): Saját kutatás alapján, 2018 (Based on own research, 2018)

4. TÁBLÁZAT

A válaszadók megoszlása az információforrások megbízhatóságának

szubjektív megítélését tekintve

(Distribution of Respondents in Terms of Subjective Judgment of Reliability of Information Sources)

\begin{tabular}{llll}
\hline \multicolumn{1}{c}{$\begin{array}{c}\text { Információforrás } \\
\text { (Information source) }\end{array}$} & $\begin{array}{c}\text { Átlag } \\
\text { (Mean) }\end{array}$ & $\begin{array}{c}\text { Medián } \\
\text { (Median) }\end{array}$ & $\begin{array}{c}\text { Módusz } \\
\text { (Mode) }\end{array}$ \\
\hline Orvosi szakvélemény (Practitioner) & 4,22 & 5,00 & 5,00 \\
\hline Szakkönyvek (Professional literature) & 3,98 & 4,00 & 5,00 \\
\hline Dietetikus véleménye (Dietetian's opinion) & 3,92 & 4,00 & 5,00 \\
\hline Védönői vélemény (Nurse's opinion) & 3,85 & 4,00 & 5,00 \\
\hline Saját szüló véleménye (Own parent's opinion) & 3,75 & 4,00 & 4,00 \\
\hline Táplálkozási tanácsadó véleménye (Dietetic consultant's opinion) & 3,74 & 4,00 & 4,00 \\
\hline Gyógyszerész véleménye (Pharmacist's opinion) & 3,55 & 4,00 & 4,00 \\
\hline Gyermekpedagógus véleménye (Teacher's opinion) & 3,28 & 3,00 & 3,00 \\
\hline Természetgyógyász véleménye (Naturopath's opinion) & 3,07 & 3,00 & 3,00 \\
\hline Más anyukák véleménye (Other mother's opinion) & 2,92 & 3,00 & 3,00 \\
\hline Közösségi rendezvények (Events) & 2,90 & 3,00 & 3,00 \\
\hline Újságcikk (Articles) & 2,75 & 3,00 & 3,00 \\
\hline Közösségi fórumok (Social Media) & 2,51 & 3,00 & 3,00 \\
\hline Bloggerek,Vloggerek véleménye (Bloggers, Vloggers) & 2,33 & 2,00 & 3,00 \\
\hline For (Source
\end{tabular}

Forrás (Source): Saját kutatás alapján, 2018 (Based on own research, 2018) 


\section{KÖVETKEZTETÉSEK ÉS}

JAVASLATOK - CONCLUSIONS AND RECOMMENDATIONS

Az eredmények alapján megállapítható, hogy már nem olyan drámai a helyzet a helytelen életmódot és táplálkozást tekintve, mint az ezt megelőző években az tapasztalható volt. Egyre többekben tudatosul, hogy mekkora súlyú nemzeti problémáról van szó. Bár még mindig sokan vannak, akik kifogások mögé rejtőznek, ha a felelősségvállalás szóba kerül, mégis úgy véljük kezd kirajzolódni az emberek elótt az a bizonyos út, amin járniuk kéne, annak érdekében, hogy egy egészségesebb, tudatosabb társadalomban élhessünk.

Viszonylag meglepő eredménynek számított, hogy a kitöltők a lelki egészséget értékelték az egészség dimenziói közül a legfontosabbnak. Ez nagyfokú nyitottságra utal, hiszen korábban az egészség fogalmát kifejezetten a biológiai egészséggel azonosították. Jó látni, hogy az emberek ilyen jelentőséget tulajdonítanak mind a lelki, a mentális, az emocionális, illetve a szociális egészségnek egyaránt.

A kapott válaszokat összegezve, a kitöltők szinte egybehangzó véleménye, hogy a szülők felelőssége egy gyermek egészséges életmódjának kialakítása. Felismerik a helytelen táplálkozás okozta problémákat és hisznek a megelőzés, a példamutatás és a szűrővizsgálatok fontosságában. Ugyanakkor úgy gondolják, hogy általában más családok nem veszik elég komolyan például a gyermekkori elhízás prevencióját, valamint az iskola se nyújt kellő információt a gyermekek számára az említett kérdésköröket tekintve, amelyet korábban is tapasztaltunk. Változtatni mások vagy akár a saját magunk életmódján, illetve berögzült szokásain nem a legkönnyebb dolog, így sokszor egyszerübb, ha a szőnyeg alá söpörjük problémáinkat. A berögzült rossz szokások korai kiküszöbölésén segíthetnénk azzal, ha az általános iskolák és gimnáziumok meghívnának az egészséges életmódban jártas szakembereket, vagy a fiatalok számára jól ismert, a témával foglalkozó életmódtanácsadót, bloggert vagy youtube videóst, például az osztályfőnöki óra keretein belül. Egyrészről így sok új információval lennének gazdagabbak a gyerekek egy kötelező óra alkalmával, másrészt egy kötetlen információcserére, beszélgetésre is alkalmat adna.

Kiderült, hogy a szülők többsége bár általában ösztönösen, intuitív módon cselekszik, fontosnak tartja a szakirodalomban leírtakat és ezeket egyaránt alkalmazza gyermeknevelésük során. Ezt az összehasonlító elemzés is alátámasztotta, hiszen a felhasználást és hitelességet tekintve a szakkönyvek az első kettő között szerepeltek mindkét táblázatban.

Fény derült arra is, hogy a legtöbben a szakorvosok véleményében hisznek, és ezt használják fel leggyakrabban. Ennek alapján úgy véljük, ha az egészségiparban szeretne egy vállalat új terméket bevezetni, a legjobb stratégiát akkor választja, ha nyilvánosságra hoz egy objektív szakorvosi véleményt érthető formában, mely alátámasztja a termék létjogosultságát és kiemeli annak előnyeit. Ezzel hitelességet kölcsönöz az adott fogyasztási cikknek és az emberek tudatában egy megbízható kategóriába pozícionálja azt.

Bár a minta nem reprezentatív, pont azt a fizetőképes és tudatosság szempontjából érzékeny csoportot sikerült összegyüjteni, akik véleménye nagyon fontos lehet mind a vállalkozások, mind a döntéshozók szempontjából.

\section{5. ÖSSZEFOGLALÁS - SUMMARY}

Kutatásunk témájának kiválasztásában az inspirált minket, hogy feltérképezzük, melyek azok a kérdéskörök, amelyek most egyrészt divatosnak számítanak, esetleg az aktuális megatrendek közé sorolhatók.

Célunk volt, hogy rávilágítsunk arra, milyen fontos a gyerekek egészségtudatos életmódra való nevelése és megfelelő tájékoztatása a témával kapcsolatban már egészen kiskortól kezdődően. Ezen belül kiemelten fontos a táplálkozás szerepe már kora gyerekkorban. Megvizsgáltuk azt is, hogy a szülők vállalják-e a felelősséget gyermekük megfelelő életmódjának és napi rutinjának kialakításában.

$\mathrm{Az}$ adatgyưjités során szekunder és primer kutatási módszertant használtuk.

Szekunder információforrásnak szakkönyveket, folyóiratok, illetve statisztikai adatbázisokat használtunk fel. A további elemzéshez 
a Google Scholar és a Science Direct online felületein található szakirodalmakat hívtuk segítségül. Főbb vázlatpontoknak a következőket választottuk: az egészséges életmód alappillérei, fogyasztói attitűdök, egészséges életmód a családban/szülői hatás az étkezésre, a szülői felelősség kérdése. Mindezt leszúkítettük a magyar lakosságra, ezen belül is azokra a szülókre, akiknek gyermekei o-14 év közöttiek. Az adatgyüjtés során külföldi, illetve magyar szerzőktől származó szakirodalmat egyaránt felhasználtunk, hogy minél hitelesebb képet kapjunk a választott témában és ezzel alátámasszuk kutatásunk létjogosultságát. A lakosság átlagos fogyasztói kosarának elemzését a Központi Statisztikai Hivatal adataira alapoztuk, melynek során fény derült arra mennyit költ egy átlagos magyar család élelmiszerre havonta, és mely élelmiszerekre költik a legtöbbet. Az egészség fogalmának változási folyamatát tekintve, a WHO által közreadott információkat is körültekintően megvizsgáltuk és felhasználtuk a cikk megírása során.

Feltáró kutatásunk során kérdőíves megkérdezést alkalmaztunk, melynek során 206 kitöltőt sikerült elérnünk (célcsoport-orientáltan), így releváns képet kaptunk a feltett kérdésköröket illetően. Primer kutatásunk célja egy olyan mélyreható kép kialakítása volt a szülői attitűdök, preferenciák, valamint nevelési szokásokat illetően, melyre az eredmények feldolgozása lehetőséget nyújtott.

Elemzéseinkhez az SPSS statisztikai programot használtuk, ezen belül is jellemzően leíró, megoszlási mutatókat, kereszttábla elemzéseket alkalmaztunk.

Úgy gondoljuk sikerült hiteles információkat gyüjteni, melyek talán egy újabb kutatás alapjául szolgálhatnak, hiszen az egészséges életmód egy olyan témakör melynek rengeteg aspektusát lehet újra és újra megvizsgálni.

\section{KöSZÖNETNYILVÁNÍTÁS -}

\section{ACKNOWLEDGEMENT}

A publikáció elkészítését az EFOP-3.6.1-162016-00022 számú projekt támogatta. A projekt az Európai Unió támogatásával, az Európai Szociális Alap társfinanszírozásával valósult meg.

\section{IRODALOMJEGYZÉK - REFERENCES}

Ábrahám, Á. - Csatordai, S.: Óvodások iskolások táplálkozási szokásai. Védőnő. 2006. 16 (6) 35-39.

Baumrind, D.: Current Patterns of Parental Authority. Developmental Psychology Monographs. 1971. 4 (1 pt.2) 1-103. DOI: https://doi.org/10.1037/hoo30372

Block, J. H.: The Child-Rearing Practices Report (CRPR): A Set of Q Items for the Descrip Tion of Parental Socialization Attitudes and Values. University of California, Institute of Human Development, Berkeley, 1965.

Busi, E.: Nevelési színterek I. A család. ELTE TTK Multimédiapedagógia és Oktatástechnológia Központ, Apertus Közalapítvány, Budapest, 2004.

Cohler, B. J. - Weiss, J. L. - Grunebaum, H. U.: Child Care Attitudes and Emotional Disturbance Among Mothers Ofyoung Children. Genetic Psychology Monographs. 1970. 82 (1) 3-47.

Hidvégi, P. - Kopkáné, P. J. - Müller, A.: Az egészséges életmód. Eszterházy Károly Főiskola, Sporttudományi Intézet, Eger, 2015.

Holden, G. W. - Edwards, L. A.: Parental Attitudes Toward Child Rearing: Instruments, Issues, and Applications. Psychological Bulletin. 1989. 106 (1) 2958.

Horváth, Á.: A fogyasztói magatartás és az élelmiszerfogyasztás jellemzői. Doktori értekezés, Gödöllő, 1996.

Fahey, T. D. - Insel, P. M. - Roth, W. T.: Fit and well: Core Concepts and Labs in Physical Fitness and Wellness. New York, McGraw-Hill, 2010.

Lantos, K. - Inántsy-Pap, J.: A család hatása az étkezési szokásokra a gyermekkori elhízás szempontjából. Acta Sana. 2012. (1) 19-23.

Lehota, J.: Élelmiszergazdasági marketing, Műszaki Könyvkiadó, Budapest, 2001.

Lipi, Sz.: A 2000. év fogyasztói társadalma. Marketing \& Menedzsment. 2000. 5 4549.

Pikó, B.: Egészségtudatosság serdülőkorban. Akadémia Kiadó, Budapest, 2002. 
Sallay, H. - Münnich, Á.: Családi nevelési attitűdök percepciója és a self-fejlődéssel való összefüggései. Magyar Pedagógia. 1999. 99 (2) 157-174.

Schaefer, E. S. - Bell, R. Q.: Development of a Parental Attitude Research Instrument. Child Development. 1958. 29 339-361.

Sulyokné Guba, J.: Kis emberek, nagy piac, avagy a gyermek fogyasztóvá válása. In Marketing \& Menedzsment. 2000. 34 (2) 39-44.

Sutton-Smith, B. - Rosenberg, B. G.: Sibling Consesus on Power Tactics. In: Goslin, D.B (Szerk.): Handbook of Socialization Theory and Research. McNally College Publishing Co., Chicago, 1966. 791-821.
Szúcs, R. S. - Széll, E.: Az anyai szerepkör a gyermekek egészségtudatos fogyasztói szocializációjában. Economica különszám. 2013. 6 (ksz) 58-66.

Tóth, I. - Gervai, J.: Szülői Bánásmód Kérdőív (H-Pbi): A Parental Bonding Instrument (Pbi) Magyar Változata. Magyar Pszichológiai Szemle. 1999. 54 (4) 551-566.

\section{JEGYZETEK * NOTES}

